\title{
THE LIMITS OF COMPETITION: REASSERTING A ROLE FOR CONSUMER PROTECTION AND FAIR TRADING REGULATION IN COMPETITIVE MARKETS.
}

\author{
Nicola Howell* and Therese Wilson\#
}

\section{Introduction}

In this paper we advocate for the continued need for consumer protection and fair trading regulation, even in competitive markets. For the purposes of this paper a 'competitive market' is defined as one that has low barriers to entry and exit, with homogenous products and services and numerous suppliers. Whilst competition is an important tool for providing consumer benefits, it will not be sufficient to protect at least some consumers, particularly vulnerable, low income consumers. For this reason, we argue, setting competition as the 'end goal' and assuming that consumer protection and consumer benefits will always follow, is a flawed regulatory approach. The 'end goal' should surely be consumer protection and fair markets, and a combination of competition law and consumer protection law should be applied in order to achieve those goals.

We begin by describing the relationship between competition law and consumer protection law in the Australian regulatory context. This is demonstrated, for example, by the enactment of the Trade Practices Act 1974 (Cth) and the establishment at the time of the Trade Practices Commission, now the Australian Competition and Consumer Commission, which has regulatory responsibilities for both competition and consumer protection.

Our paper then explores the role often accorded to consumer protection law, limiting it to intervening where there is a market failure. We argue, however, that the intervention of consumer protection law is appropriate not only in the case of market failure, but also in the case of competition failure. To explain, 'competition failure' is the term we will use to describe the phenomenon that occurs where competitive markets fail consumers in ways that might not strictly be regarded as market failure. We give examples of this, including a failure to protect disadvantaged or marginalised consumers whose preferences are not seen as

\footnotetext{
* Director, Centre for Credit and Consumer Law, Griffith University. The Centre for Credit and Consumer Law is funded by the Queensland Government's Consumer Credit Fund (administered by the Office of Fair Trading) and Griffith University.

\# Senior Lecturer, Griffith Law School and Member, Socio-Legal Research Centre, Griffith University. An earlier version of this paper was presented to the International Association of Consumer Law Conference, April 2007. Thanks to the anonymous referee for very helpful comments.
} 
priorities for traders. The point is made that competition creates both winners and losers, and that whilst competition is an important tool to use in generating good consumer outcomes, it is not sufficient to protect the losers of competition- those consumers not regarded as profitable targets.

We recognise that aspects of failures that we define as 'competition failures', such as a failure to serve low income consumers, may also be attributable to factors recognised under the umbrella of market failures. This includes information asymmetry, where lenders may lack information about lending to this sector of the community. ${ }^{1}$ However, we consider it useful to maintain the distinction between 'market' and 'competition' failures to illustrate our point that some failures seem to be regarded as grounds for intervention by the Australian government, while others do not seem to be so regarded.

The Australian consumer credit market will be presented as a case study, where low income consumers pay more for credit services than more affluent and profitable consumers, and where they may have no alternative but to access credit products which are unfair in their terms and in many respects unsafe.

In 2007, Australian government policy does not currently reflect an understanding or acknowledgement of the ways in which competitive markets might fail consumers. We argue that the role of competitive markets has been over-valued in Australian government policy, with an emphasis on removing red tape and regulatory burdens, at the risk of reducing consumer protection. There is a reluctance to impose new regulatory burdens on business in order to protect consumers, for example through the enactment of nationally consistent legislation to prohibit unfair terms in consumer contracts.

Our paper will conclude by arguing that consumer protection law should be a priority for regulators in its own right, and that ensuring competitive markets will not always be the answer.

\section{Relationship between competition law and consumer protection law}

In this part of the paper, we summarise the links between competition and consumer protection. In Australia, consumer protection law and competition law came into their own in the 1970s, with the introduction of the Trade Practices Act 1974 (Cth) and the establishment of the (then) Trade Practices Commission (now the Australian Competition and Consumer Commission). Consumer protection law and competition law were seen as complementary, and were therefore both included within the one piece of legislation and the one regulatory agency. This

\footnotetext{
${ }^{1}$ Ramsay (2006, pp 70-71)
} 
complementary nature was also expressed in the object of the Act, which is described as being:

to enhance the welfare of Australians through the promotion of fair trading and competition and provision for consumer protection. ${ }^{2}$

In this object, the reference to 'welfare' reflects a concept of economic welfare, ${ }^{3}$ rather a broader idea of social or community welfare. According to the Dawson Review of the competition provisions of the Trade Practices Act,

In economic terms, welfare will be enhanced by rising living standards in the form of higher incomes in real terms and an increase in consumer choice, by sustainable high economic growth, and by a lower unemployment rate. These benefits flow when human and other resources are used more efficiently to increase productivity and to maximise returns on investment. Competitive markets are the key to economic efficiency. ${ }^{4}$

From this perspective comes the repeated assertion that competition law and competition policy are not ends in themselves; they are simply mechanisms to achieve economic efficiency, which in turn is the vehicle for generating improved consumer (economic) welfare. ${ }^{5}$

There is broad agreement that competition policy and competitive markets benefit consumers by driving greater choice, lower prices and better quality from producers and suppliers. Those traders who meet the expressed preferences of consumers will do well; those who do not offer a competitive product or service will lose business. A competitive market is, for the most part, more beneficial to consumers than a monopolistic market. While some (including ourselves) might quibble with those statements as they apply to particular sectors in detail, few would disagree with these statements in broad principle.

Commentators have therefore suggested that competition law and consumer law 'should be seen as one subject not two'6; that competition law is 'the cornerstone of consumer protection'7; and that 'robust competition in a strong market is the primary bulwark of consumer protection'. ${ }^{8}$ For these and other commentators, competition law and consumer law are closely related, even intertwined, in their goals, objectives and outcomes.

For example, Neil Averitt and Robert Lande described the relationship in the following way: competition law and policy ensures that 'the marketplace remains

2 Trade Practices Act 1974 (Cth) s 2

${ }^{3}$ Dawson (2003, p.29)

${ }^{4}$ Dawson (2003, p. 29)

${ }^{5}$ Dawson (2003, p. 32)

${ }^{6}$ Vickers (2003, p. 4)

${ }^{7}$ Stuyck (2005, p. 27)

${ }^{8}$ Muris (2004, p. 4) 
competitive, so that a meaningful range of options is made available to consumers', ${ }^{9}$ and consumer laws are designed to 'ensure that consumers can choose effectively from among those options with their critical faculties unimpaired by such violations as deception or the withholding of material information'. ${ }^{10}$ On this analysis, grounds for intervention in markets should be restricted to the cases where there is anti-competitive conduct (competition law is the solution) and/or market failure (consumer protection law is the solution).

In this paper, we will not focus on the detail of interventions to prevent anticompetitive conduct; this is the subject of many other texts. Instead, in the next part of our paper, we focus on consumer protection interventions to overcome market failures and what we have termed "competition failures".

\section{Market failures, information asymmetry and consumer literacy}

From a theoretical, economic perspective, consumer protection legislation is seen as an appropriate response to 'market failure', that is, to situations where the competitive market process is not working as it should. For example, Chris Field suggests that

... [consumer protection] regulation is needed, and justified, where: (1) there is a demonstrable market failure (for example, what economists refer to as information asymmetries); (2) the regulation proposed is directed to addressing the market failure; (3) the regulation is the least restrictive way of achieving its remedial purpose; and (4) the regulation does not create more costs than then benefits that it seeks to achieve. ${ }^{11}$

The main market failure for consumers is often seen to be 'information asymmetry', when consumers do not have accurate, sufficient, or effective information to make an effective and informed choice between products/services and suppliers, should they wish to take up that opportunity. ${ }^{12}$ Consumer protection regulation to address this market failure includes prohibitions against misleading or deceptive conduct: ${ }^{13}$ as well as specific obligations to disclose certain information, often in a particular form and at a particular time. Australian examples include requirements for financial services licensees to provide written financial services guides, product disclosure statements, and statements of advice to retail clients, ${ }^{14}$ and requirements for credit providers to provide

\footnotetext{
${ }^{9}$ Averitt and Lande (1997, p. 713)

${ }^{10}$ Averitt and Lande (1997, p. 713-4)

${ }^{11}$ Field (2005, p. 52)

${ }^{12}$ Averitt and Lande (1997, p. 717): 'We ask that consumers be enabled to make rational choices to the extent that they wish to concentrate on doing so.'

${ }^{13}$ See for example, Trade Practices Act 1974 (Cth), ss 52, 53.

${ }^{14}$ See, for example, Corporations Act 2001 (Cth), ss 941A, 941B (Financial Services Guide); s 946A (Statement of Advice); ss 1012A, 1012B, 1012C (Product Disclosure Statement).
} 
precontractual statements, information statements, and written contracts that contain specified information. ${ }^{15}$

This focus on reducing information asymmetries through mandated information disclosure dovetails neatly with the project to develop empowered and financially literate consumers. Governments in Australia now devote significant resources to financial literacy and consumer education. In 2005, the Commonwealth Government established the Financial Literacy Foundation, with a remit to:

give all Australians the opportunity to better manage their money ${ }^{16}$

The Foundation's activities include raising awareness through media campaigns, working with education authorities to have financial literacy included in the school curriculum, research (a national study to set a benchmark of financial literacy), working with employers to increase access to financial literacy in the workplace, and developing a web-based catalogue of financial literacy projects and resources. ${ }^{17}$

The joint Australian/State/Territory Ministerial Council on Consumer Affairs also has an education strategy, with two current projects: financial and consumer education for young people, and a National indigenous consumer strategy, launched in 2005. ${ }^{18}$ And individual government agencies at all levels have also developed their own programs and initiatives. ${ }^{19}$ However, this commitment to financial literacy and consumer education is not without its critics, ${ }^{20}$ and we discuss some of the limitations of financial literacy and consumer education initiatives below.

The discussion above relates to demand-side information problems. There are also information asymmetry problems on the supply side, where consumers have more information than traders about factors relevant to cost or risk. For example,

\footnotetext{
${ }^{15}$ See, for example, Consumer Credit Code ss 12, 15, 16 (written contract document); s 14 (precontractual disclosure).

${ }^{16} \mathrm{See}$ http://www.understandingmoney.gov.au/Content/Consumer/AboutUs.aspx, viewed 31 January 2007.

${ }^{17} \mathrm{See}$ http://www.understandingmoney.gov.au/Content/Consumer/AboutUs.aspx, viewed 29 August 2007.

${ }^{18}$ Ministerial Council on Consumer Affairs Strategic Agenda September 2005, items 3.1 and 3.2, see http://www.consumer.gov.au/html/mcca projects.htm\#P268 12056 viewed 31 January 2007.

${ }^{19}$ See for example, the Australian Securities and Investments Commission's work on financial literacy (http://www.fido.gov.au/fido/fido.nsf/byheadline/Financial+literacy?openDocument) and consumer education

http://www.fido.gov.au/fido/fido.nsf/byheadline/Consumer+education+strategy+2001+to+2004?openDocu ment); the Australian Competition and Consumer Commission's Scamwatch

(http://www.scamwatch.gov.au/content/index.phtml/itemId/693900); Consumer Affairs Victoria research papers on Consumer Education in Schools, Information Provision and Education Strategies, and Social Marketing and Consumer Policy (http://www.consumer.vic.gov.au/CA256EB5000644CE/page/ListingResource-Reports $+\&+$ Guidelines? OpenDocument\&1=Home $\& 2=\sim \& 3=\sim \&$ REFUNID $=\sim \#$ Research, viewed 12/12/07).

${ }^{20}$ Consumers' Federation of Australia (2004)
} 
consumers normally know more about their personal factors relevant to credit risk or insurance risk than do credit providers or insurers.

Asymmetric information is not the only example of a market failure that might justify intervention. Others include negative externalities, where the true costs of products or services are not reflected in their price (eg environmental costs).

Although negative externalities are treated as market failures in economic theory, in practice, it seems that these externalities are rarely factored into the pricing of goods and services.

Other market failures include situations involving public goods (unlikely to be provided by the market) and free riders; 'lemons'; and transaction and switching costs (a subset of the information asymmetry problem). ${ }^{21}$ Rhonda Smith gives an example of this latter market failure in a paper published in 2000 . Smith refers to litigation by the then Trade Practices Commission in the newly deregulated and highly competitive telecommunications industry. Misleading advertisements by Telstra regarding the pricing of local calls could not be deciphered by consumers because of the significant transaction and search costs:

- $\quad$... the pricing plans for the products were complex and so more search yielded little benefit.

- this difficulty was compounded by the rapid rate of change in the industry - both technology and price offerings - so that data obtained was quickly outdated, sometimes before comparisons could be made.

- the position was worsened by the type of sale involved. Consumers were entering into a contract and so their ability to respond to new or more accurate information in the future was reduced, at least for some time. This locked them into their current supplier and locked them away from alternative suppliers. In a competitive market, this reduced the incentive of suppliers to fully inform potential customers. ${ }^{22}$

In this case, even in the absence of misleading advertising, we suspect that consumers would have found it difficult, if not impossible, to identify the most beneficial call plan.

In this same paper, Smith also suggests that a disparity in bargaining power between consumers and traders can also be considered to be a market failure, as it leaves consumers open to exploitation. ${ }^{23}$ She suggests that this disparity in bargaining power 'generally results from a lack of consumer choice or some incapacity on the part of the consumer'. ${ }^{24}$

A disparity of bargaining power is often given as a justification for consumer protection measures. However, we are not convinced that a disparity of

${ }^{21}$ Averitt and Lande (1997, p. 724-6)

${ }^{22}$ Smith (2000, p. 416)

${ }^{23}$ Smith (2000, p. 408-9)

${ }^{24}$ Smith (2000, p. 409) 
bargaining power should strictly be considered as market failure in the economic sense. On the contrary, a disparity in bargaining power is the natural outcome of consumer transactions in $21^{\text {st }}$ century markets. Markets do not have a conscience, they are not interested in ideals of distributive or social justice or fairness. ${ }^{25}$ Most of the major consumer transactions today pit an individual consumer against a large and well-resourced business, often operating at least nationally, if not globally. Even if the trader is a small business, that trader will have more experience of the transaction in question than an individual consumer. In this context, the notion of an equality of bargaining power is more illusory than real. If a disparity in bargaining power amounts to a market failure, then, almost by definition, most consumer markets in Australia would show signs of market failure.

\section{Competition Failures}

It is clear that from an economic perspective, market failures occur. In these circumstances, classical economists might concede that consumer law is an appropriate response. However, from a broader social or community welfare perspective, it is equally clear that competition and competitive markets can fail consumers. Some examples follow.

First, competitive markets, exhibiting high levels of rivalry between participants, can take advantage of confusion and, what some commentators have referred to as 'confusopoly'. ${ }^{26}$ The telecommunications sector has been a key example of this problem, as highlighted above. Competitive financial services, electricity and gas markets can also exhibit similar characteristics. ${ }^{27}$ In these markets, a prohibition of misleading or deceptive conduct will not necessarily solve consumer problems, nor will mandatory disclosure of information.

Relatedly, competitive markets can also fail consumers when policy makers are too optimistic about the benefits of disclosure regulation. For example, whilst acknowledging the importance of information disclosure initiatives, Geraint Howells cautions against over-reliance on the information initiatives, highlighting the following limitations: ${ }^{28}$

- consumers are burdened by a lack of time, and 'it would be wrong to assume that all information was actually being read';

\footnotetext{
${ }^{25}$ For example, a submission by the Australian Chamber of Commerce and Industry to the National Competition Policy Review (2004, p. 10) criticises any suggestion that markets should take into account social equity: 'Where governments seek to achieve some social equity or other (re)distributional outcomes on the basis of 'public interest' or 'public benefit', these [should] be pursued through other policy channels, such as taxation and/or public expenditure.'

${ }^{26}$ This concept is referred to in Organisation for Economic Co-operation and Development (2006, p. 11).

${ }^{27}$ Sylvan (2004a, p. 196)

${ }^{28}$ Howells (2005, pp. 356 - 362). See also Wilhelmmson (2007, pp. $\left.214-215\right)$
} 
- information disclosure benefits middle-class consumers, and in segmented markets, any increase in standards from informed consumers is likely to have little impact on poorer consumers;

- consumers can have a lack of alternatives (real or perceived), and in this circumstances, consumers 'may rationally decide not to make use of information';

- there may be market impediments to acting on the information by switching;

- behavioural economics provides some insights into the 'irrational' responses of consumers, which suggest that the consumer who is 'reasonably well informed and reasonably observant and circumspect' is in fact the atypical consumer.

Joshua Gans also uses behavioural economics to illustrate a failing of competition. He suggests that consumers' lack of self-control and naivety will lead consumers to purchase too much of a product at a given price, and that 'this gives rise to welfare reductions even in competitive markets and ... these things are exacerbated by the strength of competition. ${ }^{29}$ He notes: 'Competition is good at providing what consumers demand and not what they would otherwise want, so welfare may be harmed. ${ }^{30}$ Here, he distinguishes between what consumers demand, as demonstrated through their purchasing activity, and what they would in fact want if behavioural biases and short-comings had no impact on their decision-making. By implying that consumer demands through their purchasing practices are not necessarily reflective of actual wants, Gans appears to be questioning the reliance on competition as an efficient market mechanism. ${ }^{31}$ Gans shows support for more interventionist forms of regulation that might, for example, regulate disconnection fees, automatic contract renewal and switching costs. ${ }^{32}$ In contrast, the traditional information disclosure response would not restrict the imposition of those fees and costs, but would simply require their disclosure.

The findings of behavioural economists highlight the numerous ways in which consumer behaviour and decision making processes diverge from that expected of the 'economically rational' consumer. Under the model used by traditional economists:

consumers who individually may not always be rationally calculating, en masse and in general can be modelled as if they behave rationally. Preferences are determined on the basis of maximised self-interest. And preferences in the shortterm are stable; consumers approach markets with given preferences. ${ }^{33}$

\footnotetext{
${ }^{29}$ Gans $(2005$, p. 2$)$

${ }^{30}$ Gans $(2005$, p. 3)

${ }^{31}$ Gans (2005, p. 10): 'While I would hesitate to say that a move away from competition would be similarly desirable, there is at least a case to be made here'

${ }^{32}$ Gans (2005, p. 11)

${ }^{33}$ Organisation for Economic Co-operation and Development (2006, p 13).
} 
However, studies in behavioural economics suggest the existence of a range of biases that are inconsistent with 'rational' behaviour of consumers. These biases have been summarised by the Organisation for Economic Co-operation and Development ${ }^{34}$ as included the following:

- Behaviour and decisions can be influenced by the way in which choices are framed: 'If options are framed in terms of possible losses, risk aversion tends to dominate; if options are framed in terms of possible gains people are more likely to take up those options.'

- Some behaviours depend upon the way in which choices are framed (suggesting that consumer preferences are not stable).

- People find it very difficult to estimate probabilities, and have a general difficulty in assessing the risk of very low probabilities.

- People are reluctant to sell or give up a good that they already own (endowment, or status quo bias).

- In the face of many choices, people can choose not to choose, and opt out of search and comparison activities.

- The order in which options are presented can influence choice (default bias).

Space considerations prevent us from exploring and applying the findings of behavioural economics in more detail. However, these and other findings support our argument that undue reliance on disclosure to protect consumers can result in poor outcomes.

The broad insights offered by behavioural economics can provide a useful supplement to the more traditional economics/market analysis used by policy makers. However, these insights are yet to permeate consumer policy in Australia to any significant extent. The key focus of policy makers in this country continues to be on competition, information disclosure and financial literacy.

Highly competitive markets may also fail consumers by facilitating the business of rogue and fraudulent traders. As noted above, the theoretical perfectly competitive market is one that has low barriers to entry and exit, with homogenous products/services, and numerous suppliers. However, markets with low barriers to entry and exit can also attract unscrupulous operators, who may have no reputation to protect. In at least some jurisdictions in Australia, there are no licensing, registration, or accreditation requirements for credit providers, and very few limits on product cost. ${ }^{35}$ As a result, lenders (including lenders offering very high cost credit) can readily establish operations. If lenders are particularly

\footnotetext{
${ }^{34}$ Organisation for Economic Co-operation and Development (2006, pp. 39 - 41)

${ }^{35}$ The State of Queensland provides one example. Under the Consumer Credit (Queensland) Act 1994 (Qld), there are no requirements that must be met before a business seeks to provide consumer credit, although, on the application of the relevant government official, the Court can make an order prohibiting or restricting a person from providing consumer credit (s. 23). Unlike some other Australian jurisdictions, there is no ceiling on interest rates or fees and charges for consumer credit in Queensland. Office of Fair Trading, Queensland (2006, p. 14).
} 
targeting consumers excluded from mainstream finance, and who are likely to be desperate for finance, reputation concerns may not be a high priority.

The phenomena of 'reverse competition', where suppliers compete to encourage brokers or advisers to recommend their products over others, can also result in higher prices to consumers, and/or poor recommendations. ${ }^{36}$

Finally, competitive markets can particularly fail disadvantaged or marginalised consumers, whose preferences are not seen as priorities for traders. Competition and competitive markets do not require business to provide goods or services to all consumers or to provide products or services that are unprofitable.

Businesses do not compete for the custom of those who are not seen as attractive or profitable customers, and competition does not necessarily do anything to ensure that all consumers have a range of options, at appropriate pricing levels. ${ }^{37}$ As Peter Cartwright notes, an absence of choice can result:

not from inadequate competition, but from a competitive financial services industry taking an economic decision only to offer more profitable products ... ${ }^{38}$

As we noted earlier, markets are not interested in social justice or equity, even though these matters might be important for consumers. ${ }^{39}$ And clearly, the benefits of competitive markets are not evenly spread amongst consumers competition creates both winners and losers.

Competition then, is often (but not always) needed to generate good consumer outcomes, but it is not sufficient. ${ }^{40}$ Where competition fails to benefit or protect consumers, consumer protection interventions may also be needed.

\section{The Consumer Credit Market - a case study.}

In this part of the paper, we will examine the consumer credit market in Australia as a case study. We will argue that that market has failed low income consumers who have not benefited from competition within it, thus demonstrating a need for consumer protection to be given priority by policy makers.

\footnotetext{
${ }^{36}$ See for example, Hunter (2006, pp. 4-5); also Call for new laws to protect against unhealthy competition, Radio National AM transcript 29 March 2004, available at www.abc.net.au/am/content/2004/s1076015.htm, viewed 14/02/2007.

37 In the financial services sector, this leads to the phenomena of financial exclusion - see Howell and Wilson (2005, pp. 132 - 133).

${ }^{38}$ Cartwright (2004, p. 212)

${ }^{39}$ Organisation for Economic Co-operation and Development (2006, pp. 17 and 40). See also Smith and King (2006), cited in Organisation for Economic Co-operation and Development (2006, p. 59)

${ }^{40}$ Fels (2005, p. 51)
} 
The Australian consumer credit market is generally regarded as a competitive one, at least with regard to housing and personal loans. A study published by Justin Malbon in 1999 noted of the housing and personal loans market that:

There are a large number of lenders, there is visible and aggressive advertising on interest rates and most consumers shop around for their loans before deciding to make a purchase. ${ }^{41}$

Even in relation to personal loans, however, the consumer credit market in Australia has failed low income consumers in three key ways. Firstly, there is a general lack of competition when it comes to "unprofitable consumers", who as a result pay higher prices for products and services than more affluent and "profitable" consumers; secondly, one consequence of that lack of competition is that products targeted at low income consumers in this market have been found to contain unfair contract terms, including terms as to price; and thirdly, these products are often unsafe in the sense that they can result in substantial detriment to consumers.

\section{The losers of competition - the unprofitable consumers}

Chris Field has noted that low income consumers tend to be the 'losers' of competition, given the distributional effects of markets. ${ }^{42}$ This group is likely to grow as the income divide in Australia grows at a rate exceeding that of other OECD countries. ${ }^{43}$

Whilst economic growth is said to be a benefit of competition policy, that growth is of no benefit to many low income consumers. This highlights the essential nature of effective consumer law in protecting the interests of those consumers, notwithstanding the appearance of a competitive market. As Field puts it:

The poor can never be an inconvenience to the greater good. Consumer organisations must be a voice, when others are too often silent, for a fair distribution of the great dividends that our open and free market creates. ${ }^{44}$

This reflects a Rawlsian approach that:

The outcomes of markets are only justified to the extent that they benefit the least-advantaged group in society in the long run. ${ }^{45}$

The example that Field gives of low income consumers as 'losers' of competition is in relation to bank fees, which tend to be lower for those customers with

\footnotetext{
${ }^{41}$ Malbon (1999, p. 9) There was found to be substantially less competition in the credit card market and in the linked credit market where credit is offered on the purchase of goods with an interest free period.

${ }^{42}$ Field (2005, p. 54)

${ }^{43}$ See for example, Australian Bureau of Statistics (2007b); Ziguras (2002).

${ }^{44}$ Field (2005, p. 54)

${ }^{45}$ Ramsay (2007, p. 34 referring to Rawls, J. (1971) A Theory of Justice, Cambridge Massachusetts, pp. $100-108)$.
} 
residential mortgages, but higher for those customers 'without a loan, who have low balances and have a high-volume of transactions'. ${ }^{46}$ This seems to confirm Connolly and Hajaj's observation in their report on financial services and social exclusion in 2001, that despite the prediction of the Wallis Inquiry ${ }^{47}$ that increased competition in the financial services market would bring about affordable financial services for all Australians, no such competition has emerged for low income consumers. ${ }^{48}$

The consumer credit market in Australia, which is the focus of this part of our paper, is another example of the failure of competition to benefit low income consumers. An inability to access small, short-term loans on reasonable terms by people on low incomes is one aspect of the phenomenon described as 'financial exclusion', defined more broadly in the Australian context as:

The lack of access by certain consumers to appropriate low cost, fair and safe financial products and services from mainstream providers. ${ }^{49}$

Where people are excluded from accessing credit from 'mainstream' credit providers such as banks and credit unions in order to acquire essential household items or to meet emergency bills, they have the options of seeking credit from the not-for-profit sector through No Interest Loans Schemes (NILS) or Low Interest Loans Schemes (LILS) ${ }^{50}$; or from the high cost, fringe credit sector. ${ }^{51}$ Whilst NILS and LILS programs are currently offered on a relatively small scale in Australia, there is evidence that high cost fringe lending is growing rapidly ${ }^{52}$ and that this is likely to be the primary source of small loans for people on low incomes.

The financial exclusion of low income consumers as it relates to an inability to access small, short-term credit at reasonable rates and on reasonable repayment terms, is a failure of competition. We define the term "low income consumer" in this context flexibly enough to include those individuals who are denied access to mainstream financial services because of their income level, without stipulating what that income level must be. Current definitions used elsewhere seem to set the bar very low. For example, in seeking to qualify for a Centrelink (Australian Social Security) health care card, a single person with no dependants is regarded as an eligible, low-income earner where he or she earns a gross annual income of no more than AUD $\$ 21,840 .{ }^{53}$ This is also the standard adopted by National

\footnotetext{
${ }^{46}$ Field (2005, p. 54 quoting from Banking Fees in Australia, Reserve Bank Bulletin, April 2003)

${ }^{47}$ Wallis (1996)

${ }^{48}$ Connolly \& Hajaj (2001, p. 33)

${ }^{49}$ Chant Link and Associates (2004, p. 58)

${ }^{50}$ For an explanation of NILS and LILS schemes in Australia, see Consumer Affairs Victoria (2006, pp. 90

$-91)$.

${ }^{51}$ See discussion in Consumer Affairs Victoria (2006, p. 37)

${ }^{52}$ Again, see discussion in Consumer Affairs Victoria (2006, p. 37); and also Office of Fair Trading,

Queensland (2006, p. 12)

${ }^{53}$ Centrelink (2006)
} 
Australia bank in offering its 'Step Up Loan', a low interest loan for amounts between $\$ 800$ and $\$ 3000$ at a rate of $6.99 \%$ per annum, offered in partnership with Good Shepherd Youth and Family Service. ${ }^{54}$ This is likely to fall short of the income level at which consumers might resort to high cost fringe credit, for example a small quantitative study conducted in Victoria in 2002 found the average income of fringe credit borrowers to be in the vicinity of $\$ 24,000$ per annum. ${ }^{55}$

Some indication of the income level at which people face financial stress and indebtedness (and, given the links between indebtedness and financial exclusion ${ }^{56}$, then impliedly financial exclusion) can be derived from statistics compiled by the Australian Bureau of Statistics in 2003 and 2004. ${ }^{57}$ Those statistics were used to divide income levels in Australia into deciles, the lowest three deciles being comprised of people whose median disposable weekly incomes were $\$ 262$ (or $\$ 13,624$ per annum).

This group is described as "low economic resources households", of which $78 \%$ derive their income from government pensions and allowances. They are characterised by higher probabilities of financial distress indicators in that only $13 \%$ of these households have a an ability to save, compared with $37 \%$ of other households; $28 \%$ of these households spend more than they receive compared with $16 \%$ of other households; $12 \%$ of these households report going without meals compared with $2 \%$ of other households; and $52 \%$ report an inability to raise $\$ 2000$ to meet an emergency expense compared with $9 \%$ of other households. ${ }^{58}$ This final indicator is, of course, highly indicative of financial exclusion.

Whilst those in the 'low economic resources households' group would have to be regarded as low-income consumers for the purposes of this paper the point needs to be made that these income levels set the bar low, and would not accommodate all of those who have been found to turn to alternative credit providers to meet their credit needs due to a lack of access to mainstream credit providers. ${ }^{59}$ There is therefore a "gap" in the market in relation to which there is currently not even an attempt to provide alternative forms of credit to exploitative fringe credit.

The growth in the fringe credit market has been linked to a failure on the part of mainstream credit providers such as banks to serve the needs of low income

\footnotetext{
${ }^{54}$ National Australia Bank (2006a)

${ }^{55}$ Wilson (2002)

${ }^{56}$ Department of Trade and Industry (U.K.), (2003, p. 77).

${ }^{57}$ Australian Bureau of Statistics, (2007a)

${ }^{58}$ Australian Bureau of Statistics 2007

${ }^{59}$ Wilson, (2002) Unfortunately there has been no more recent or more comprehensive quantitative study of fringe credit borrowers in Australia.
} 
consumers. ${ }^{60}$ This failure is no doubt due to perceptions of risk and lack of profitability in this market due to the costs of providing small personal loans. Earlier in this decade in Australia we have seen closures of banks in low income areas, and banks trying to attract and retain a "more profitable" group of customers. ${ }^{61}$ lain Ramsay's observations in relation to banks in Canada seem equally apt in the Australian context:

There is evidence that banks, notwithstanding their public relations efforts, are not strongly committed to cultivating lower income clients or branches which serve lower income areas which do not generate sufficient profits in this age of shareholder-driven capitalism. ${ }^{62}$

Some Australian banks have certainly embraced the concept of corporate social responsibility, extending to meeting the credit needs of low income consumers, more readily since a report by the Parliamentary Joint Committee on Corporations and Financial Services in 2004, which stated amongst other things that:

the Government has an obligation to intervene should the market fail to look after the needs of consumers especially in the area of access to banking and financial services. ${ }^{63}$

That same report also recommended that the Australian Department of Treasury consider the enactment of legislation such as the Community Reinvestment Act 1975 (USA), which effectively links banking licences to investment in and service provision to low and moderate income communities, in the event that Australian banks did not meet their social obligations on a voluntary basis. ${ }^{64}$

Following this there has been support for NILS programs by both Westpac ${ }^{65}$ and National Australia Bank ${ }^{66}$, and LILS programs introduced by both $\mathrm{ANZ}^{67}$ and National Australia Bank ${ }^{68}$ in partnership with community organisations. Unfortunately these schemes currently operate on a small scale, and primarily in the state of Victoria. ${ }^{69}$ This leaves low income consumers, seeking small loans to acquire essential household items or to meet emergency bills, in a situation

\footnotetext{
${ }^{60}$ Ministerial Council on Consumer Affairs (2003, p. 5)

${ }^{61}$ Connolly \& Hajaj (2001, pp. 13\&16)

${ }^{62}$ Ramsay (2000, p. 5)

${ }^{63}$ Parliamentary Joint Committee on Corporations and Financial Services (2004, p. 307)

${ }^{64}$ Parliamentary Joint Committee on Corporations and Financial Services (2004, p. 304) To date, there has been no Australian government response to this report nor its recommendations.

${ }^{65}$ Westpac (2004)

${ }^{66}$ National Australia Bank (2006b). In April 2006 NAB announced a \$30 million commitment over 3 years to both NILS and LILS programs.

${ }^{67}$ ANZ (2006)

${ }^{68}$ National Australia Bank (2006a)

${ }^{69}$ Consumer Affairs Victoria (2006), Office of Fair Trading, Queensland (2006)
} 
where they are left with no choice but to pay exorbitant fees ${ }^{70}$ for credit, with the perverse result that those consumers are paying more for credit services than more affluent consumers. Ramsay notes that:

individuals are paying too much for services in these markets compared to consumers in middle income markets and that this is unfair. ${ }^{71}$

Within the fringe credit market itself there seems to be no incentive to compete for business by offering reasonable rates. Low income consumers are in poor bargaining positions, and in any event the fringe credit industry has submitted that it is unable to operate at what more affluent consumers might regard as reasonable rates, due to its members' own operating costs and the nature of small amount lending which lacks economies of scale. ${ }^{72}$ It may be that the fringe credit industry is simply not one that can be conducted both profitably and justly. There is a clear case for regulatory intervention in this market to protect low income consumers, by encouraging and facilitating non-exploitative lending to meet the demand for small loans.

Despite an obvious market, competition has failed to provide low-income consumers with short-term credit at rates comparable to those for more affluent consumers. Low-income consumers have identified the sort of financial product they require. It is a matter of social equity that it be provided to them at a fair and just price. ${ }^{73}$

\section{Unfair Contract Terms}

As stated above, a low income consumer in need of small amount, short-term credit is not in a strong bargaining position. Such a consumer may fall prey to unfair contract terms. An example of such a term given in the recent Victorian Credit Review was:

As continuing security for the payment of all debts, liabilities and obligations of the borrower to [credit provider], the applicant grants a security interest to and in favour of [credit provider] in all of my present or after acquired personal property and proceeds there from including, without limitation the vehicle as described in Schedule 'A'.

One study demonstrated that a low income consumer seeking credit in the fringe market will be primarily concerned with accessing loan moneys from any credit provider willing to lend to them, and will not regard himself or herself as having any choice but to borrow on the terms offered. ${ }^{74}$ This is particularly the case

\footnotetext{
${ }^{70}$ When converted to annual percentage rates the fees charged on payday loans, a form of fringe credit, can range from $235 \%$ to $1300 \%$ or more per annum. See Office of Fair Trading, Queensland (2000) and Centre for Credit and Consumer Law (2006).

${ }^{71}$ Ramsay (2000, p. 20)

${ }^{72}$ Consumer Affairs Victoria (2006)

${ }^{73}$ Wilson $(2002$, p. 82)

${ }^{74}$ Malbon (1999, p. 78)
} 
given that standard form contracts are likely to be offered on a 'take it or leave it basis' and are likely to be favourable to the credit provider. ${ }^{75}$ Noting that many contracts used in the fringe credit industry:

contain terms and conditions heavily biased in favour of the credit provider,

the Victorian credit review report went on to note further that

vulnerable and disadvantaged consumers have a limited capacity to read and understand the full implications of terms and conditions and this enables credit providers to exploit weaknesses in current regulation. ${ }^{76}$

There are mechanisms under the Australian Uniform Consumer Credit Code enabling consumers to apply to the court to reopen unjust transactions or review unconscionable or other interest charges under hardship or unconscionability provisions. ${ }^{77}$ It is unlikely, however, that low income consumers will have the resources or inclination to bring applications before the court. A research study undertaken in the U.K. demonstrated that low income consumers are unlikely to take legal action in relation to a loan dispute, on the basis of factors such as cost, a sense of powerlessness, and a fear of acrimonious disputes. ${ }^{78} \mathrm{~A}$ more recent NSW study of responses to legal problems in disadvantaged areas found that, of a range of civil, criminal and family problems, credit/debt problems had one of the highest rates of inaction for survey participants. ${ }^{79}$

Further, borrowers in the fringe credit market do not have access to alternative dispute resolution, such as exists for borrowers from mainstream lenders under the Banking and Financial Services Ombudsman scheme and other similar schemes $^{80}$. The Victorian Credit Review commented that:

There is no requirement for small amount lenders to have any external dispute resolution. Many consumer advocates recommended that commercial small amount credit providers be required to belong to an accredited alternative dispute resolution scheme. ${ }^{81}$

\footnotetext{
${ }^{75}$ Hadfield, Howse \& Treblicock (1998, p. 142)

${ }^{76}$ Consumer Affairs Victoria (2006, p. 183)

77 Sections 70(1), 70(2)(1) and 72 Uniform Consumer Credit Code

${ }^{78}$ Genn $(1999$, p. 101)

${ }^{79}$ Coumarelos (2006, p. 99), although the sample size for credit/debt matters was only 26.

${ }^{80}$ There are currently in Australia 8 industry based external dispute resolution services, including the BFSO but also, for example, the Credit Ombudsman Service, the Credit Union Dispute Resolution Centre, and the Financial Cooperative Dispute Resolution Scheme. See Pearce (2007)

${ }^{81}$ Consumer Affairs Victoria (2006, p. 94) This is because the obligation to belong to an approved External Dispute Resolution scheme is imposed only upon holders of an Australian Financial Services licence.

Unless a credit provider also offers other retail financial services (deposit-taking, insurance, etc), it is not required to obtain an Australian Financial Services Licence. See Corporations Act 2001 (Cth) ss 911A (need for an Australian financial services licence); $912 \mathrm{~A}(\mathrm{~g})$ (licence obligation to have a dispute resolution system); 766A (definition of financial service), and 765A (credit is not a financial product).
} 
Even in the event that a complaint concerning unfair contract terms in the fringe market gets to court, the courts have tended to require evidence of procedural unfairness (concerned with 'the circumstances under which the transaction came about' ${ }^{2}$ ) in order to grant relief. As one of us has noted elsewhere, substantive unfairness, being related to the terms of the contract themselves, has in practice only led to relief being granted in a small number of cases. ${ }^{83}$

The presence of unfair contract terms and the lack of effective mechanisms for complaint about those terms by low income consumers are again indicative of the need for strong consumer protection regulation in this area, involving legislation to prohibit unfair terms in consumer contracts. ${ }^{84}$

\section{Unsafe Products}

There is evidence of substantial detriment being suffered by low income consumers who have accessed credit from the fringe market. ${ }^{85}$ There are five key problems that have been identified in relation to fringe credit, that make these products unsafe. ${ }^{86}$ These are loan 'rollovers'; debt collection methods; taking household items as security; failure to assess capacity to repay; and avoiding the operation of the Uniform Consumer Credit Code. We will focus here on debt collection methods, the loan 'rollovers' and a related issue of failure to assess capacity to repay, which seem particularly hazardous.

Examples given of debt collection methods employed by fringe credit providers include threatening to access social security benefits, threatening to repossess goods which are not actually the subject of a formal security arrangement, contacting a borrower's employer direct seeking payment of wages to the credit provider, and general harassment and coercion. ${ }^{87}$ The taking of security over household items has been described as 'blackmail security' in that its only purpose is to provide some threat to ensure repayment.

Consumer organisations have reported that some fringe credit providers use the threat of repossession to create a sense of fear for some borrowers. This can then give the fringe credit provider an effective priority over other lenders as borrowers maintain payment to the fringe credit provider for fear of having their essential household goods repossessed, even if they declare themselves bankrupt. ${ }^{88}$

\footnotetext{
${ }^{82}$ Howell (2006, p. 448)

${ }^{83}$ See discussion in Howell (2006). It is suggested that this judicial reluctance to intervene in relation to substantive unfairness is largely attributable to concerns about upholding the notion of freedom of contract.

${ }^{84}$ See discussion in Howell (2006, pp.463-464)

${ }^{85}$ Consumer Affairs Victoria (2006, pp. 119-120) and Office of Fair Trading, Queensland (2006, p. 13)

${ }^{86}$ Consumer Affairs Victoria (2006, p. 119)

${ }^{87}$ Consumer Affairs Victoria (2006, p. 121)

${ }^{88}$ Consumer Affairs Victoria (2006, p. 122)
} 
'Rollovers' are a feature of payday loans, which are one category of fringe credit. They are short-term loans, usually for a period of approximately 14 days, for small amounts in the vicinity of $\$ 250.00 .{ }^{89}$ Of great concern is the practice of allowing borrowers to 'rollover' the loan on payment of an additional loan fee, which is said to be 'the beginning for many of an uncontrollable debt spiral' 90 wherein borrowers pay, over a period of time, an amount well in excess of the original loan amount often without reducing the principal amount owed.$^{91}$ Given the very short time period allowed for loan repayment in the case of a payday loan, it is likely that many low income consumers will not have the necessary lump sum to repay the loan in full on the due date, and will need to take up the 'rollover' option. The 'rollover' has been described as:

one of the most controversial features of payday loans because it carries great financial risk for consumers and is perhaps the key to the lucrative nature of the business for lenders ${ }^{92}$,

and is a feature which pulls borrowers

into a series of repeated loan transactions that may be financially devastating to the borrower ${ }^{93}$

There is evidence indicating that payday lenders actively target those on low incomes who will be unable to make due payments and will need to roll loans over. This has in fact been described in a recent study in the U.S. as 'the foundation of the payday lending business model'. ${ }^{94}$ That same report noted that 'the profitability of payday lending is driven by volume, which is in turn driven by rollovers'. ${ }^{95}$ Evidence of this 'business model' in Australia includes the opening of payday lending outlets in predominantly low income suburbs, and experiences reported by financial counsellors. ${ }^{96}$ Further, research conducted in Australia in 2002 showed that a large number of payday borrowers earned less than $\$ 401.00$ per week. ${ }^{97}$

Closely related to the question of 'rollovers' is the failure on the part of fringe lenders to assess borrowers' capacities to repay 'so the credit does not place them in financial hardship'. ${ }^{98} \mathrm{~A}$ failure to assess capacity to repay within the loan term has been found to 'contribute to real financial distress' ${ }^{\prime 99}$ which can only exacerbate problems of over-indebtedness and poverty in the Australian

${ }^{89}$ Wilson $(2004$, p. 160$)$

${ }^{90}$ Syvret (2001, p. 30)

${ }^{91}$ Wilson (2004, p. 160)

${ }^{92}$ Lott \& Grant (2002, p. 22)

${ }^{93}$ Lott \& Grant (2002, p. 13)

${ }^{94}$ King, Parrish \& Tanik (2006, p. 3 )

${ }^{95}$ King, Parrish \& Tanik (2006, p. 8)

${ }^{96}$ Field (2002, p. 37)

${ }^{97}$ Wilson (2002, p.9)

${ }^{98}$ Consumer Affairs Victoria (2006, p. 92)

${ }^{99}$ King, Parrish \& Tanik (2006, p.8) 
community. Competition, in the sense of having many players in the market, has not protected consumers.

At the very least there is a role for consumer protection regulation to prohibit the use of the 'rollover' mechanism; to require lenders to properly assess borrowers' capacities to repay; and to give borrowers reasonable periods of time to repay loans in accordance with their capacities, without payment of additional fees. More generally, the hazards of fringe credit referred to above would arguably justify a significant interference with the free running of this market, in order to protect vulnerable consumers.

\section{Rationale for consumer protection interventions}

The limitations of competition and competitive markets demonstrated by this case study as well as examples given earlier in this paper, give rise to alternative theories for consumer protection regulation, which do not rely solely on the classical ideas of market failure.

However, these alternative rationale(s) for consumer protection interventions are not always easy to articulate, and do not necessarily form a coherent picture. As Louise Sylvan has noted, with the exception of regulation to stop consumers being misled:

Other consumer protection regulation, while plentiful and much of which is crucial, is not woven together into a well-structured pattern. ${ }^{100}$

Commentators have therefore struggled to define consistent and comprehensive categories for consumer law. In part this may be because consumer problems cover all aspects of the economy, have elements of civil, criminal, contract, tort and other laws, and are often 'on the border line of private/public and social/commercial problems'. ${ }^{101}$ By way of illustration, some categorisations of consumer law suggested by others are provided below:

- Anthony Duggan has suggested that consumer protection interventions are made on the basis of economic efficiency considerations, loss distribution considerations, and/or paternalistic concerns. ${ }^{102}$

- Geraint Howells suggests that consumer protection interventions should focus on promoting competition, achieving individual justice, and realising social justice. ${ }^{103}$

\footnotetext{
${ }^{100}$ Sylvan (2004a, p. 193)

${ }^{101}$ Howells and Weatherill (2005, p. 660)

102 Duggan (1997, p. 73)

${ }^{103}$ Howells (1993, p. 335)
} 
- John Vickers talks of consumer regulation in terms of the problems that it is seeking to address - duress and undue pressure; information problems pre-purchase; and undue surprises post-purchase. ${ }^{104}$

- In contrast, lain Ramsay suggests a 'third way' approach to consumer credit regulation, one that both recognises the importance of the market, and of empowering consumers within that market, and also focuses on the relevance of social policy in achieving goals that cannot be met relying on the market alone. ${ }^{105}$

These categories are not necessarily comprehensive. Interestingly, for some commentators, including Howells, it appears that the categorisation of consumer law incorporates broader community or social ideals that may require intervention even in a competitive market that provides for overall consumer (economic) welfare. This suggests that consumer law should do more than perfect the functioning of the market; it should have more distributive goals. ${ }^{106}$

There is another argument that equity or distributive justice is not an appropriate goal for markets, and/or that market regulation is not effective in achieving equitable goals. An example relevant to this paper is that of interest rate ceilings, with some commentators of the view that such mechanisms introduce credit rationing and do not ultimate benefit consumers on low incomes. ${ }^{107}$

One of the more recent classifications in Australia is provided by Sylvan, who suggests that regulation to protect consumers takes one of three forms:

(i) Competition-enhancing rules (eg information disclosure requirements, prohibitions against misleading conduct);

(ii) Rules to minimise harm in the provision of goods and services (eg product safety); and

(iii) Rules to protect consumers from inappropriate behaviour of traders (eg prohibitions against undue coercion, or unacceptable disconnection from essential services). ${ }^{108}$

Again, however, this classification is only a starting point, as Sylvan herself effectively acknowledges. ${ }^{109}$ It raises more questions than it answers. For example, how much harm can/should be minimised? When is behaviour to be deemed inappropriate or unacceptable, rather than simply a consequence of a market system that is based on parties utilising their own strengths and

\footnotetext{
${ }^{104}$ Vickers $(2003$, p. 3)

${ }^{105}$ Ramsay (2004, p. 5)

${ }^{106}$ Howells (1999, p. 298)

${ }^{107}$ For example, Durkin (1993, p. 824-825); Engel and McCoy (2002, p. 1313)

${ }^{108}$ Sylvan (2004a, p. 194). In an earlier paper, Sylvan categorises consumer protection rules as Market conduct and information rules (competition enhancing); sensible society rules; and equitable rules (Sylvan 2004b, p. 6).

${ }^{109}$ Sylvan (2004a, p. 205)
} 
preferences to get the most favourable outcome and/or seeking to enforce contract terms 'agreed upon' in advance.

An added complication is the fact that consumers are not homogenous in their preferences, skills, ability, socio-economic status and other characteristics. It may not be possible to design consumer policy that meets the needs of all consumers, including the marginalised and the vulnerable. ${ }^{110}$ If this is the case, there are difficult issues to grapple with in a policy sense, including whose interests should prevail if a proposed policy response benefits one group of consumers, but does not benefit, or even harms, another. Sylvan illustrates this point by asking: 'How does a regulator handle situations where different subsets of consumers are likely to have outcomes in different quadrants - some are disadvantaged by an intervention while others are unaffected or better off?'111

These considerations highlight the difficulties and complexities associated with designing effective consumer policy. It is not within the scope of this paper to come up with a consistent and comprehensive rationale for consumer protection interventions; this is the topic for another day. ${ }^{112}$ However, this discussion illustrates the support amongst commentators for interventions in consumer markets in circumstances that may not equate to market failure from an economic perspective.

\section{Australian Government approach - rhetoric vs reality}

Unfortunately, this general acknowledgment amongst many academics, and consumer advocates, ${ }^{113}$ of the ways in which competitive markets can fail consumers does not seem to be reflected in Australian government policy and practice in $2007 .{ }^{114}$ Advocates for changed or increased consumer protection mechanisms designed to meet the complexities and challenges of consumer markets are finding their calls for intervention ignored or pilloried as unnecessary and/or paternalistic. Instead, the government perspective appears to be that competitive markets are the true goal and that:

... confident consumers know they have real power - the power of choice. And they know how to use that power. ${ }^{115}$

\footnotetext{
${ }^{110}$ Although another perspective is that 'most consumers are vulnerable in at least some situations', Wilhelmsson (2007, p. 213)

${ }^{111}$ Sylvan (2004a, p. 204)

${ }^{112}$ However, it may be that the current Productivity Commission Inquiry into Australia's Consumer Policy Framework will tackle this task. See Productivity Commission (2007, pp. $14-15)$

${ }^{113}$ See for example, Tennant (2006, pp. 4-5).

${ }^{114}$ The Liberal/National coalition was in government from 1996 to November 2007.

${ }^{115}$ Pearce (2005)
} 
The government appears to take a narrow approach to the concept of market failure, and tends to give little weight to what we've termed 'competition failure' as a justification for market intervention.

This trend of overvaluing the role of competitive markets is manifested in government policy and practice in a number of ways.

The first is the National Competition Policy's legislative review program. The Competition Principles Agreement, signed in 1995, committed the Australian, State and Territory governments to '... list, review, and where appropriate, reform all legislation which restricts competition'. ${ }^{116}$ While legislation that has overall benefits for the community can pass the legislative review hurdles, the review program effectively reverses the onus of proof. Advocates for the retention of legislation with anti-competitive effects have to demonstrate that the removal of the restrictions would not be in the interests of the community. ${ }^{117}$

The second is an almost zealous concern about eliminating red tape and reducing regulatory burdens on business. ${ }^{118}$ Consumer protection legislation is often a target of these initiatives. ${ }^{119}$

Of course, implementing a rigorous legislative review program, and reducing unnecessary red tape and regulatory burdens are laudable goals. Ineffective regulation imposes costs on the whole community. ${ }^{120}$ Our concern is, however, that these programs too strongly emphasis the merits of unfettered markets and the costs of regulation. It appears that reviewers focus on questions of 'How does this legislation impede competition?' and 'How much does it cost business?'. For consumer protection matters, we suggest that it would be more appropriate to first ask 'What are the consumer problems and what is the fairest, most efficient and effective solution or solutions?'

Third, there appears to be a retreat from a focus on legislation, regulation and enforcement to deal with consumer issues. The proposal for nationally consistent legislation to prohibit unfair terms in consumer contracts has apparently stalled, and there is some suggestion that it has stalled at the national level. ${ }^{121}$ Despite a Parliamentary Joint Committee report recommending federal regulation of the property investment market, the Australian Government 'wishes to continue to investigate all options'. ${ }^{122}$ Similarly, it seems that calls for nationally uniform legislation for finance and mortgage brokers will not necessarily result in federal

\footnotetext{
${ }^{116}$ Productivity Commission (2005, p. 16)

${ }^{117}$ Productivity Commission (2005, p. 16)

118 The most recent review being Banks, G (2006).

${ }^{119}$ See for example, Banks (2006, pp. 51, 106)

${ }^{120}$ Banks (2006, p. 12).

${ }^{121}$ See for example, Standing Committee on Law and Justice (2006, pp. 54 - 55). It is also worth noting that the Ministerial Council on Consumer Affairs' regular Communiqués refer only to the possibility of State and Territory legislation, see Ministerial Council on Consumer Affairs (2006).

${ }^{122}$ Ministerial Council on Consumer Affairs (2006)
} 
legislation, despite the obvious parallels between financial advisers (regulated by the Corporations Act 2001 (Cth)) and credit advisers. ${ }^{123}$

Part of the problem may be attributed to the now pervasive requirement that new regulatory proposals must undergo a regulatory impact assessment. This process requires an assessment of the costs and benefits of legislation and any alternatives to legislation. We agree that this is an important process. However, in practice, given the difficulties of quantifying diffuse benefits that are not necessarily economic, this cost-benefit analysis can almost set social regulation (including consumer protection regulation) up to fail. We suspect that it will be relatively easy for business to quantify the costs of new legislation (for example, of meeting new information disclosure requirements), but describing and costing consumer benefits is much more difficult. As the Productivity Commission notes:

Often, the benefits of government intervention in promoting the interests of consumers and efficient market outcomes are widely spread and difficult to quantify. ${ }^{124}$

Finally, it seems fair to say that in recent times, the Australian Government has failed to provide national leadership on consumer policy, ${ }^{125}$ perhaps reflecting the lack of priority that this area seems to merit within the Government.

We hope that the Government's current inquiry into national consumer policy will start to reverse this trend. However, phrases such as 'unnecessary regulation', 'promoting certainty and consistency for business and consumers' and 'the extent to which more effective use can be made of self-regulatory, co-regulatory, consumer education and consumer information approaches' are prominent in the terms of reference for the inquiry. ${ }^{126}$ These issues should be important considerations in any review of national consumer policy and administration. However, our concern is that a focus on red tape and regulatory burdens is looking in the wrong direction. Instead, there should be a more proactive aim to:

get the right consumer policies in place, and then minimise regulation to achieve them. ${ }^{127}$

\footnotetext{
${ }^{123}$ One industry member has suggested that: 'Common sense would see the Federal Government resolve the issue by an extension of its existing financial service laws, some of which already impact on the day-today activities of finance brokers. However, it would appear that considerably more consumer blood will need to be let before it becomes an imperative of the Federal Government.' See http://www.mortgagemagazine.com.au/detail article.cfm?articleID=659, viewed 14/02/2007.

${ }^{124}$ Productivity Commission (2007, p. 23). See also Goldring (1990, p. 128), who notes in relation to wider social costs and benefits, that '... such costs and benefits are notoriously difficult to quantify'.

${ }^{125}$ Fels $(2005$, p. 56) suggesting that their involvement is 'a little bit reluctant and limited'.

126 The Terms of reference for the review are available at $\mathrm{http}$ :/www.pc.gov.au/inquiry/consumer/tor.html, viewed 14/02/2007.

${ }^{127}$ Allan Fels and Fred Brenchley 'Consumers last in line' Australian Financial Review 16 January 2007, p 46.
} 
Fortunately, the Productivity Commission's Issues Paper for this inquiry seems to take a more nuanced approach, ${ }^{128}$ although the difficulties of balancing the competing priorities in the terms of reference for the inquiry should not be underestimated.

Interestingly, this attitude of the Australian Government and the positioning of consumer policy as a relative low priority policy area contrasts with the explicit commitment to consumer policy as a 'horizontal measure' in European law. Under Article 153(2) EC, 'Consumer protection requirements shall be taken into account in defining and implementing other Community policies and activities'. Thus, in the European Union, consumer protection 'should be taken into account inter alia in the shaping of competition policy'. ${ }^{129}$ In contrast, consumer protection seems to be considered an after-thought in Australia, despite Sylvan's recent suggestion for a 'reframing of the competition lens so it's seen from a consumer framework'. ${ }^{130}$

Thus, although competition is regularly described by the Australian Government as not being an end in itself, its actions suggest that competition, reduced market interference, and reduced regulatory burdens, have now become the end game.

\section{Conclusion}

In this paper, we have described the ways in which markets can fail consumers; with information asymmetry being the key problem. Consumer protection interventions to reduce market failures can lead to more competitive markets, often for the ultimate benefit of consumers.

However, we have also sought to describe the ways in which even competitive markets can fail consumers, using the consumer credit market in Australia as a case study. We have showed that, despite its competitiveness, the consumer credit market has particularly failed low income consumers through failing to provide appropriate products; imposing unfair contract terms; and offering unsafe products. These and other 'competition failures' should lead to calls for the imposition of regulatory requirements that are not necessarily 'competitionenhancing' rules, but are rules that reflect the more difficult to particularise concerns of social equity, fairness, and the broader community welfare.

Our analysis shows that consumer protection rules are still essential, even in competitive markets. At a broad level, competition and competitive markets can never be the complete answer to consumer problems because there is a difference in scale and perspective. Competition law and policy looks to the

\footnotetext{
${ }^{128}$ For example, Productivity Commission (2007, p. 13).

${ }^{129}$ Weatherill (2007, p. 199), even if there may be some deficiencies in institutional backup.

${ }^{130}$ Sylvan (2004b, p. 8)
} 
macro picture; it is not interested in the impact of competition on individual businesses, and similarly, it is not interested in micro-cases of unfairness. ${ }^{131} \mathrm{It}$ might influence the conduct of traders at a broad level, and over time, but does not directly impact on the time-specific relationship between an individual consumer and an individual trader. ${ }^{132}$ However, consumers are very much interested in the micro-level, in the individual relationships that they have (or do not have) with traders. A perspective that competition will, over time, weed out rogue traders and unfair practices, does not offer much comfort to those affected by such practices today.

In contrast, consumer law can and should influence the daily individual transactions that occur across the market. This should particularly be the case in relation to consumer transactions in industries that exhibit information asymmetry problems at either supply or demand sides, and provide essential services giving rise to considerations of social equity and access. The banking industry is one such industry and the consumer credit market has been used in this paper as an example of a market exhibiting these features.

Competition law and policy is about economics and markets. But consumers are not just economic beings, doggedly seeking to get the best deal for themselves regardless of broader considerations. Among other things, the preference of at least some consumers for products and services that have minimal environmental impact; or that reflect fair trade and working conditions, illustrate the importance of other considerations. We acknowledge that traditional theories of markets encompass environmental considerations and other externalities, however, we suggest that economic policy in practice tends to ignore these issues.

Consumer law can and should sit alongside competition law, and respond to both economic and social concerns and considerations. The alternative is that many consumers will be left to fend for themselves, and inequities will prevail.

Competition law and consumer law are related, and are both equally important to the effective operation of markets in the interests of the community as a whole. The key here is the equal importance of the two aspects of law. Giving effective priority to competition, as appears to be the approach of the Australian Government in 2007, risks ignoring the needs and realities of many consumers, to the ultimate detriment of the community as a whole.

Consumer law and policy should not be a secondary consideration for Governments. It should be a high level priority in its own right. Responding effectively to consumer issues requires us to acknowledge the strengths and limitations of both competition law and consumer law; to articulate the problems

${ }^{131}$ Cseres (2005, p. 1)

132 Buttigieg (2005, p. 193) 
and their genesis; and to identify one or more solutions without being blinkered by the mantra that competitive markets are always the answer. 


\section{Reference List}

ANZ (2006) http://www.anz.com/aus/values/community/progress loans.asp, viewed 13 December 2006.

Australian Bureau of Statistics (2007a) Australian Social Trends.

Australian Bureau of Statistics (2007b) "Income and Income Distribution Australia 2005-2006", released 02/08/2007, viewed 16/10/2007 at http://abs.gov.au/AUSSTATS.

Australian Chamber of Commerce and Industry (2004) ACCI Submission to the Productivity Commission Review of National Competition Policy and Arrangements, available at http://www.pc.gov.au/inquiry/ncp/subs/sub110.pdf, viewed 14/12/2007.

Averitt, N. and Lande, R. (1997) 'Consumer sovereignty: A unified theory of antitrust and consumer protection law' 65 Antitrust Law Journal $713-756$.

Banks, G (2006) Rethinking Regulation: Report of the Taskforce on Reducing Regulatory Burdens on Business.

Buttigieg, E (2005). 'Consumer and competition policies: synergy needed' 15(5) Consumer Policy Review 192 - 197.

Cartwright, P. (2004). Banks, Consumers and Regulation. Oxford, Hart Publishing.

Centre for Credit and Consumer Law (2006) Submission to Office of Fair Trading, Queensland: Managing the cost of consumer credit in Queensland, discussion paper.

Centrelink, http://www.centrelink.gov.au/internet/internet.nsf/payments/conc cards iat.htm\#q ualify, viewed 13 December 2006.

Chant Link \& Associates (2004) A Report on Financial Exclusion in Australia, ANZ.

Connolly, C \& Hajaj, K (2001) Financial Services and Social Exclusion. Financial Services Consumer Policy Centre, University of NSW, Chifley Research Centre.

Consumer Affairs Victoria (2006) The Report of the Consumer Credit Review. 
Consumers Federation of Australia (2004) Submission to the Consumer and Financial Literacy Taskforce Discussion Paper "Australian Consumers and Money", available at http://www.consumersfederation.com/documents/CFAresponseCFLTaskforceDiscussonPaperfinal 001.pdf.

Coumarelos, C, Wei, Z and Zhou, A (2006) Justice Made to Measure: NSW Legal Needs Survey in Disadvantaged Areas, Law and Justice Foundation of NSW, Access to Justice and Legal Needs, Volume 3.

Cseres, K (2005) Competition Law and Consumer Protection, Kluwer Law International

Dawson, D (2003) Review of the Competition Provisions of the Trade Practices Act.

Department of Trade and Industry (U.K.) (2003) Fair, Clear and Competitive: the Consumer Credit Market in the $21^{\text {st }}$ Century.

Duggan, A. "Saying Nothing with Words" (1997) 20 Journal of Consumer Policy $69-88$

Durkin, T. "An economic perspective on interest rate limitations" (1993) 9 Georgia State University Law Review 821 - 838.

Eardley, T (2004) Australian Social Trends No 2: Economic ResourcesHousehold Assets, Liabilities and Financial Stress.

Engel, K. and McCoy, P. "A tale of three markets: the law and economics of predatory lending" (2002) 80 Texas Law Review 1255 - 1366.

Fels, A (2005) 'Reflections of a former regulator on the consumer affairs scene' in Consumer Affairs Victoria (2005) Essays in Australian Consumer Affairs: An occasional series, March, pp $51-57$.

Field, C. (2005) 'Competition, Consumer Protection and Social Justice -

Providing a Consumer's Voice'. Australian Business Law Review, 33( 1), 51-54.

Field, C (2002) 'Payday Lending- an Exploitative Market Practice', Alternative Law Journal, 27(1), 36.

Gans, J. S. (2005). "'Protecting consumers by protecting competition': Does behavioural economics support this contention?" Competition and Consumer Law Journal 13: 1-11.

Genn, H (1999) Paths to Justice: What People Do and Think About Going to Law. Oregon: Hart Publishing. 
Goldring, J (1990). 'Consumer Law and Legal Theory: Reflections of a Common Lawyer' 13(2) Journal of Consumer Policy 113 - 132.

Howell, N. (2006). "Catching up with consumer realities: The need for legislation prohibiting unfair terms in consumer contracts." Australian Business Law Review 34(6): 447-466.

Howell, N. and T. Wilson (2005). "Access to consumer credit: the problem of financial exclusion in Australia and the current regulatory framework." Macquarie Law Journal 5: 127-148.

Howells, G. (2005). "The Potential and Limits of Consumer Empowerment by Information." Journal of Law and Society 32(3): 349 - 370.

Howells, G. and S. Weatherill (2005). Consumer Protection Law. Hants, England, Ashgate Publishing Limited.

Howells, G (1993) 'Contract Law: the Challenge for the Critical Consumer Lawyer' in Wilhelmsson, T (ed), Perspectives of Critical Contract Law.

Hunter, J (2006) Testimony before the House Committee on Financial Services Subcommittee on Housing and Community Opportunity: Title Insurance Cost and Competition, Consumer Federation of America, available at http://www.consumerfed.org/pdfs/Title Insurance Testimony042606.pdf, viewed 14/02/2007.

King, U; Parrish, L \& Tanik, O (2006) Financial Quicksand: Payday lending sinks borrowers in debt with $\$ 4.2$ billion in predatory fees every year. Center for Responsible Lending, U.S.

Lott, S \& Grant, M (2002) Fringe Lending and 'Alternative' Banking: The Consumer Experience. Public Interest Advocacy Centre, Canada.

Malbon, J (1999) Taking Credit: A Survey of Consumer Behaviour in the Australian Consumer Credit Market.

McColl, B; Pietsch, L and Gatenby, J (2002) Income and welfare. Special articleHousehold Income, Living Standards and Financial Stress.

Ministerial Council on Consumer Affairs (2006) Joint Communiqué Ministerial Council on Consumer Affairs Meeting Tuesday 16 and Wednesday 17 May 2006

Ministerial Council on Consumer Affairs (2003) Long Term Regulation of Fringe Credit Providers Discussion Paper. 
Muris, T (2004) The Federal Trade Commission and the Future Development of US Consumer Protection Policy, George Mason Law \& Economics Research Paper No 04-19, available at http://ssrn.com/abstract=545182.

National Australia Bank (2006a) http://www.national.com.au/About Us/0,82040,00.html, viewed 13 December 2006.

National Australia Bank (2006b) http://www.national.com.au/About Us/0,81306, 00.html, viewed 13 December 2006.

Office of Fair Trading, Queensland (2006) Managing the Cost of Consumer Credit in Queensland Discussion Paper.

Office of Fair Trading, Queensland (2000) Payday Lending- A Report to the Minister of Fair Trading.

Organisation for Economic Co-operation and Development (2006) Roundtable on Demand-side Economics for Consumer Policy, Summary Report, Directorate for Science, Technology and Industry, Committee on Consumer Policy, DSTI/CP(2006)3/FINAL, available at http://www.oecd.org/dataoecd/31/46/36581073.pdf.

Parliamentary Joint Committee on Corporations and Financial Services (2004) Money Matters in the Bush: Inquiry into the Level of Banking and Financial Services in Rural, Regional and Remote Areas of Australia.

Pearce, C (2005) 'Opening Address to Consumer Representatives' Forum' (Speech delivered at the Consumer Representatives' Forum, Melbourne Australia, 15 June 2005), available from http://parlsec.treasurer.gov.au/cjp/content/speeches/2005/010.asp.

Pearce, C (2007) 'Opening Address to the Financial Industry Complaints Service Annual Conference' (Speech delivered 6 March 2007), available from http://www.treasurer.gov.au/cip/content/speeches/2007/002.asp

Productivity Commission (2007) Consumer Policy Framework, Productivity Commission Issues Paper, January.

Productivity Commission (2005) Review of National Competition Policy Reforms, Report No. 33, 28 February. 
Ramsay, I. (2007) Consumer Law and Policy: Text and Materials on Regulating Consumer Markets, $2^{\text {nd }}$ edition. Oregon, Hart Publishing.

Ramsay, I. (2006) "Consumer Law, Regulatory Capitalism and the 'New Learning' in Regulation" Sydney Law Review 28(9) 9-35.

Ramsay, I. (2004) 'Consumer Credit Regulation as "The Third Way"? (Speech delivered at the Australian Credit at the Crossroads Conference, Melbourne Australia, 8 November 2004).

Ramsay, I (2000) Access to Credit in the Alternative Consumer Credit Market, British Columbia.

Smith, R. and King, S. "Insights into consumer risk: Building blocks for consumer protection policy" in Organisation for Economic Co-operation and Development (2006) Roundtable on Demand-side Economics for Consumer Policy, Summary Report, Directorate for Science, Technology and Industry, Committee on Consumer Policy, DSTI/CP(2006)3/FINAL, pp $54-67$, available at http://www.oecd.org/dataoecd/31/46/36581073.pdf.

Smith, R. L. (2000). "When competition is not enough: Consumer protection." Australian Economic Papers: 408-425.

Standing Committee on Law and Justice (2006) Unfair terms in consumer contracts, Report 32, November, NSW Legislative Council.

Stuyck, J. (2005). "EC Competition Law After Modernisation: More Than Ever in the Interests of Consumers." Journal of Consumer Policy 28: 1 - 30.

Sylvan, L. (2004a) "Activating competition: The consumer - competition interface" Competition and Consumer Law Journal 12, 191-206.

Sylvan, L. (2004b) "A Global View of Consumer Issues: Then and Now" (Speech delivered at the American Council on Consumer Interests $50^{\text {th }}$ Anniversary Conference, 1 April 2004, Washington, USA).

Syvret, P (2001) 'The Quick and the Debt', The Bulletin, 6 February.

Tennant, D (2006) 'The dangers of taking the consumer out of consumer advocacy', speech to the National Consumer Congress, Melbourne, March 2006, available at: http://www.carefcs.org/srcfiles/The-dangers-of-taking-the-consumerout-of-consumer-advocacy---16-March-2006.doc.

Vickers, J. (2003). 'Economics for Consumer Policy'. British Academy Keynes Lecture, 29 October. 
Wallis, S. (1996) Financial Systems Inquiry Final Report ("Wallis Inquiry Report")

Weatherill, S. (2007). "The Links Between Competition Policy and Consumer Protection" The Yearbook of Consumer Law 2007 187-209.

Westpac (2004) Pressing On: 2004 Social Impact Report.

Wilhelmsson, $\mathrm{T}$ (2007) 'The Informed Consumer v the Vulnerable Consumer in European Unfair Commercial Practices Law - A Comment' The Yearbook of Consumer Law 2007211 - 228.

Wilson, D. (2002) Payday Lending in Victoria- A Research Report, Consumer Law Centre Victoria.

Wilson, T. (2004) The inadequacy of the current regulatory response to payday lending. Australian Business Law Review, 32, 159-172.

Ziguras, S. (2002) Measuring the income divide: How does Australia compare?, viewed 16/10/2007 at http://www.onlineopinion.com.au/view.asp?article=1868. 